\title{
МІСЦЕ ДУХОВНОСТІ У ПІДГОТОВЦІ ФАХІВЦЯ-РЕАБІЛІТОЛОГА
}

\author{
Кіровоградський інститут розвитку людини

\section{PLACE OF SPIRITUALITY IN TRAINING OF A SPECIALIST- RECREATION THERAPIST}

К. Л. Чурпій

\author{
K. L. Churpiy
}

\author{
Kirovohrad Institute of Human Development
}

\begin{abstract}
У роботі висвітлено питання важливості духовності в підготовці фахівця фізичної реабілітації. Духовність с однією із складових у проведенні ефективної реабілітації, і тому проблема підготовки фахівців фізичної реабілітації с важливою не лише з вузько медичної точки зору. Процес підготовки фахівця з фізичної реабілітації мас включати питання щодо формування духовності, виховання його як глибоко духовної людини з високими людськими якостями.
\end{abstract}

The article adduces the importance of spirituality in training of a physical rehabilitation specialist. Spirituality is one of the components in conducting the effective rehabilitation and therefore the problem of training in physical rehabilitation is important not only from a narrow medical perspective. The process of training in physical rehabilitation should include questions on the formation of spirituality, his upbringing as deeply spiritual man with high human qualities.

Вступ. Запровадження і розробка нових технологій, розвиток науки і техніки вимагають відповідної підготовки фахівців, в тому числі і в медицині. Лише фахівець високого рівня зможе освоювати нові технологіі, інтегрувати досягнення різних спеціальностей і застосовувати їх з максимальною користю і віддачею для пацієнта. Тому підвищення вимог щодо підготовки майбутніх спеціалістів не стало винятком для підготовки спеціалістів з реабілітації.

На сьогодні проблема виховання майбутнього фахівця набуває особливої актуальності. Технічний процес не сприяє розвитку духовного процесу. Тому пріоритетом розвитку суспільства повинно стати духовне вдосконалення людини і ії духовний розвиток, для переходу людства на новий виток еволюційного розвитку від людини розумної до людини духовної з високими моральними якостями.

Відомий педагог В. О. Сухомлинський наголошував: “Відсутність духовності призводить до порожнечі в душі" [1].

Під реабілітацією розуміється процес відновлення здоров'я, структурно-функціональних можливостей організму, працездатності і креативності людини, потерпілої внаслідок захворювань, травм, інших несприятливих фізичних, виробничих, соціальнихй інших чинників [2].

Фізична реабілітація як процес і результат відновлення порушених функцій організму внаслідок різних причин створює умови для подальшого нормального функціонування і розвитку організму людини.

У практичній діяльності спеціаліст із фізичної реабілітації стикається з різними проблемами, які йому потрібно вирішувати для повного і швидкого одужання пацієнта. При проведенні фізичної реабілітації, як правило, необхідно проводити психічну, соціальну, трудову та інші види реабілітації. В багатьох випадках робота реабілітолога пов'язана з дітьми різних вікових груп, що потребує додаткових знань для роботи 3 ними. Тобто фізична реабілітація - складова частина медичної, соціальної, професійної реабілітації. Фізична реабілітація - це система заходів для відновлення втрачених фізичних можливостей і інтелектуальних здатностей, відновлення психічної рівноваги $і$ належного функціонального стану організму, переконання пацієнта у можливості відновлення втрачених ним функцій. Особливого підходу і співчуття потребують діти, хворі, які поряд з реабілітацією потребують догляду. Тому, крім підготовки по реабілітації, реабілітолог має мати знання з усіх вищевказаних питань, в тому числі духовного спрямування.

Основна частина. Метою роботи є теоретичне обгрунтування доцільності формування духовності у майбутніх фахівців з фізичної реабілітації. Розглядаючи і виходячи з визначення фізичної реабілітації, бачимо, що проведення реабілітації потребує велико-

(С) К. Л. Чурпій 
го гуманізму, небайдужості і співпереживання, прагнення своєю працею допомогти хворим людям, безкорисливості і великого терпіння. Фахівці реабілітації перед собою в першу чергу мають бачити людину, яка потребує відновлення здоров'я, якій потрібна допомога в плані духовному і моральному, а не просто об'єкт реабілітації. Людина, яка потребує реабілітації, крім відновного лікування, має мати розуміння ії проблем з боку реабілітолога і духовну підтримку. Процес фізичної реабілітації проходить через взаємодію людини з людиною і він не повинен втрачати людської суті.

Досягнення цілі реабілітації можливо лише тоді, коли $\epsilon$ співпереживання до пацієнта, душевне ставлення до нього. Але духовність і душевність генетично взаємопов'язані. Душевність розкривається як здатність до співчуття та милосердя, як любов до ближнього, що починається з любові до самого себе, як терпимість та щиросердність. Душевність співвідноситься із світом соціально-моральних почуттів людини [3].

Між поняттям “духовність” і “душевність” існує взаємозв’ язок. Як грунтом зростання бездуховності $\epsilon$ бездушність, так і грунтом зростання бездушності, у свою чергу, є бездуховність [4].

Головною причиною багатьох хвороб Біблія вважає гріхи - вчинки людини, пов' язані з неприйняттям релігійних цінностей. Поняття гріха у масовій свідомості ототожнюється із вчинками людини, несумісними з мораллю, підвладними тягарю земних тлінностей. Тому Біблія закликає: “Не роби зла і тебе не осягне зло" [5].

Іоан Золотоустий підкреслює, що більша частина хвороб від гріхів, але деякі бувають і від безтурботності: пияцтво, бездіяльність [6].

I знову ми вертаємося до духовності у попередженні захворювань і відновлення порушеного здоров'я. Лише людина високодуховна, яка дотримується людської моралі, може попередити в багатьох випадках захворювання і допомогти собі й іншим при порушенні здоров'я.

\section{Література}

1. Сухомлинский В. А. Избранные произведения : в 5-ти т. / В. А. Сухомлинский.-К. : Рад. школа, 1979-1980.-Т.5.-678 c.

2. Пересадин Н. А. Реабилитология. Стратегия и тактикаэффективного восстановления здоровья. Монография/Н. А. Пересадин, Т. В. Дьяченко.-Луганск : Знание, 2004.-408 с.

3. Тюріна Т. Г. Духовне виховання є й самовиховання цілісної людини / Т. Г. Тюріна // Педагогіка і психологія. 1999. - № 7-8. - С. 23.
Тому при підготовці спеціалістів з реабілітації одним 3 факторів, який необхідний у програмі підготовки фахівців, має бути духовність. Духовність є тією потенційною суттю людини, яка забезпечує їй повноцінний розвиток і саморозвиток. Духовність є результатом становлення людини, і в розвитку духовності серед майбутніх фахівців ведуча роль відводиться викладачеві-педагогу. "У людини, яку ми виховуємо, повинні бути святі істини і святі імена, святі принципи і святі незаперечні, непорушні правила поведінки" [7].

Викладач має передавати своїм вихованцям духовні цінності, накопичені старшими поколіннями, постійно працювати з тим духовним потенціалом, який закладений у душі кожного майбутнього фахівця. Завдання викладача - допомогти в розкритті цього потенціалу, розвинути власні людські можливості, зберегти свою людську гідність, націлити на розвиток духовності і душевності у студентів. Разом з тим майбутньому фахівцю прищеплюється любов до постійного вдосконалення у своїй професії, до постійного підвищення кваліфікації. Бо, як написано в Біблії, “Сину мій! Від юності твоєї віддайся науці і до сивини твоєї найдеш мудрість” [8].

Тому постає питання підготовки викладачів 3 новими цілісними орієнтаціями, що засновані на духовних пріоритетах. Викладач має володіти відповідними знаннями й уміннями, що забезпечать формування в молодих фахівців таких етичних критеріїв, як здатність до співпереживання, співчуття, терпіння, безкорисливості. Разом з тим сприяти розвитку активної життєвої позиції, творення і творчості, моральному становленню і культурному збагаченню майбутніх фахівців.

Висновок. Духовність є однією із складових у проведенні ефективної реабілітації, і тому проблема підготовки фахівців фізичної реабілітації є важливою не лише з вузько медичної точки зору. Процес підготовки фахівця з фізичної реабілітації має включати питання щодо формування духовності, виховання його як глибоко духовної людини з високими людськими якостями.

4. Щербань П. М. Формування духовної культури особистості / П. М. Щербань // Рідна школа. - 1999. - № 7-8. С. 23.

5. Біблія. Сірах 7: 1.

6. Голос православ'я. -2000. - 15 квітня. -С. 6-7.

7. Сухомлинський В. О. Вибрані твори : в 5 т. / В. О. Сухомлинський. -К. : Рад. шк., 1997.- Т. 4.-С. 391-626.

8. Біблія. Сірах 6: 18. 